\title{
UNFAIR INFORMATION PRACTICES RELATED TO MEAT AND MEAT PRODUCTS IN POLAND
}

\author{
Aleksandra Kowalska, $\mathrm{PhD}^{1}$ \\ Faculty of Economics, Maria Curie-Skłodowska University
}

\begin{abstract}
The aim of this paper was to recognize the scale and types of the food adulteration practices associated with meat and meat products from Poland. The vulnerability of food supply chains to fraud/adulteration is growing as a result of globalisation, which is expanding the scope and scale of the incidence of food fraud/adulteration. Both the intentional and unintentional adulteration of food can lead to a public health threat, and cause severe economic consequences. Meat and meat products are the most common targets for adulteration in Poland and the EU. Since meat and meat products hold a key position in food production and consumption in Poland, it is in both the industry's and government's interests to eliminate adulteration in the meat supply chain. The methodological approach was to first review the literature to define and outline the challenge of food adulteration, and then to build a database on the basis of IJHARS decisions regarding adulterated meat and meat products, and to analyse them in detail. An analysis of the data revealed that most cases infringed Article 7.1(a) of Regulation (EU) 1169/2011 on the provision of food information to consumers concerning fair information practices.
\end{abstract}

Keywords: food adulteration, mislabelling, meat and meat products

JEL codes: D40, E23, F19, F69, M21, L66

\section{INTRODUCTION}

Even though fraudulent food has been around for thousands of years, only within the last 200 years, during the industrial revolution and the rise of the 'anonymous consumer' concept, has a real explosion of this phenomenon occurred (Kowalczyk, 2015). The vulnerability of food supply chains to fraud/adulteration is growing as a result of globalisation, long food supply chains, the growing anonymity of the food market, market pressure to reduce food prices, incoherent food laws within countries, ineffective sanctions imposed, the ineffective actions of food control institutions, and so on (Spink and Moyer, 2011; Kowalczyk, 2015; Marvin et al., 2016). As long as food fraud/adulteration is profitable to perpetrators, consumers, trade competitors and authorities will continue to tackle this problem. Furthermore, globalisation is extending the scope and scale of food fraud occurrences (Spink et al., 2017). Food fraud can lead to a public health threat and pose potentially catastrophic economic impacts. The goal is not to catch food fraud but to prevent it (Moyer, DeVries and Spink, 2017). Spink and Moyer (2011) claim that

\footnotetext{
${ }^{1}$ Corresponding author: pl. Marii Curie-Skłodowskiej 5, 20-031 Lublin, Poland, aleksandra.kowalska@umcs.lublin.pl, $+48505944006$
} 
although it is governments' responsibility to lay down clear legal conditions, it is the responsibility of the industry to mitigate food fraud risks. However, such measures are not yet widely being adopted in food safety management systems (Silvis et al., 2017).

EU food law is not defining food fraud and/or adulteration, but is certainly covering the problem. Protecting consumers' health and life, and their economic interests, are major concerns of this law (Korzycka and Wojciechowski, 2017). Article 8.1 of Regulation (EC) $178 / 2002$, in laying down the general principles and requirements of food law [...] states that food law shall aim... at the prevention of fraudulent or deceptive practices, the adulteration of food, and any other practices which may mislead the consumer. Article 9.1(b) of Regulation (EU) 2017/625 on official controls and other official activities, established to ensure the application of food and feed law [...] states that competent authorities shall perform official controls on all operators regularly, on a risk basis, and with the appropriate frequency, taking account of [...] any information indicating the likelihood that consumers might be misled, in particular as to the nature, identity, properties, composition, quantity, durability, country of origin or place of provenance, or method of manufacture/production, of food. Regulation (EU) $1169 / 2011$ on the provision of food information to consumers provides a basis for consumers to make informed choices and to make safe use of food. Article 7.1(a) of Regulation 1169/2011 on fair information practices states that food information shall not be misleading, particularly as to the characteristics of the food, and, in particular, as to its nature, identity, properties, composition, quantity, durability, and so on.

\section{THEORETICAL BACKGROUND}

The European Commission has developed four key operative criteria to distinguish whether a case listed in the EU Food Fraud Network and the System for Administrative Assistance \& Food Fraud (EU FFN \& SAAFF) should be considered as food fraud, or another form of non-compliance, namely (1) the violation of EU law, (2) the intention, (3) economic gain, (4) the deception of customers (European Com- mission, 2016). Food fraud includes the subcategory of economically motivated adulteration (EMA), i.e. deception for economic gain using food products, ingredients or packaging, including activities such as substitution, unapproved additions or enhancements, misbranding or misrepresentation, tampering, counterfeiting, using stolen goods, and others (Spink and Moyer, 2011; Manning and Soon, 2014; Manning, 2016). The U.S. Food and Drug Administration (FDA) defines EMA as the fraudulent, intentional substitution or addition of a substance in a product for the purpose of increasing the apparent value of the product or reducing the cost of its production, i.e. for economic gain (Spink and Moyer 2011).

The definitions of adulterated foodstuffs in Poland are not in step with other definitions, in which intent is an inherent aspect of adulteration. The Polish legislator concentrates on mislabelling, particularly regarding product composition. Both intentional and unintentional actions are considered as adulteration (Supreme Administrative Court, 2013). Under Article 3 of the Act on Safety of Food and Nutrition (2006) (Food and Nutrition Safety Act, hereinafter: FNSA), adulterated foodstuff is determined as a foodstuff whose composition or other properties have been changed without informing the consumer, or a foodstuff altered in order to conceal its intrinsic composition or other properties, and affecting its safety. Under Article 3 of the Act on the Commercial Quality of Agricultural and Food Products (2000) (hereinafter: ACQAFP), an adulterated agricultural and food product is described as a product whose composition does not comply with the provisions of regulations regarding the commercial quality of individual foodstuffs, or a product altered (including mislabelling) in order to conceal its intrinsic composition or other properties, as long as the non-compliances violate consumer interests. An operator which produces, packs and/or places adulterated food on the market, carries legal liability for the action. FSNA has introduced legal sanctions imposed for adulteration which harms consumers' health and life, and ACQAFP has introduced sanctions imposed due to the infringement of consumers' economic interests. Thus, two separate procedures might be opened in the case of one adulterated food product (Voivodship Administrative Court, 2010). 
Meat-derived products are the most common targets for adulteration in Poland and the EU. The 2016 annual report of the EU FFN \& SAAFF shows that the most food fraud cases listed in the system concern meat and meat products, including poultry $(26.7 \%$ of all 176 food fraud cases identified) (Kowalska, 2017). An analysis of the 427 IJHARS (Main Agricultural and Food Products Quality Inspection, Poland) administrative decisions regarding adulterated agrifood products from 2013-2017 show that the most irregularities occurred in meat and meat products $(32 \%$ of the decisions), flour, cereal and bakery products $(19 \%)$, and delicatessen products $(11 \%)^{2}$. Meat and meat products are important staple foods in the EU. These products hold a key position in food consumption in Poland, as the average yearly per-capita consumption of meat and meat products is fifth, after the consumption of milk and milk products, vegetables, cereals and bakery products, and potatoes (GUS, 2017). Moreover, the consumption of meat-derived products has been systematically growing (it has increased from 2005 to 2016 by 8.9\%) (GUS, 2017). A study by Kosicka-Gębska et al. (2017), based on a nationwide online survey conducted in 2015 on a sample of 1,000 Polish consumers, showed that over $40 \%$ of respondents ate meat several times a week, and $34 \%$ consumed it every day. Rising wealth is causing the growth of meat products' consumption in both developing and highly developed countries. This is unjustifiable while the overconsumption of meat leads to many health problems, e.g. cardiovascular disease, diabetes, overweight and obesity (Chechelski, Kwasek and Mroczek, 2016).

Meat production is one of the most important agricultural sectors in the EU, with four major meatproduct categories - pigs, poultry, bovine, sheep and goat meat being produced, consumed and traded (Janiuk, Jarosiński and Ribberink, 2015). Animal production - covering the output of animals and animal products - accounts for about $43 \%$ of the total EU-28 agricultural output (Eurostat, 2015) and 36\% of the total Polish agricultural output $(98 \%$ of it can be attributed to bovine, pig and poultry meat) (GUS, 2016; Stańko and Mikuła, 2016). Pork and poultry dominate meat consumption in Poland. Poland is a net importer of pig meat, but a net exporter of bovine meat and poultry meat (around $80 \%$ of domestic production of these types of meat is exported) (Stańko and Mikuła, 2016).

Recently, the European Common Agricultural Policy (CAP) has been modified so as to stimulate the production of qualitative, nutritious, and affordable meat, i.a. through the 'greening' of agricultural systems (Eurostat, 2015). The EU is one of the leading meat producers worldwide, accounting for more than $16 \%$ of the total meat production, and around $15 \%$ of the meat trade worldwide. China, the US and the EU are respectively the first-, second- and third-ranking meat producers in the world economy (Pawlonka, 2017). Poland ranks among the 10 top exporters of meat in the EU (Janiuk, Jarosiński and Ribberink, 2015). The main EU producers and processors of meat are Germany, France and Spain. The Netherlands, Belgium and Italy are marked by especially high work efficiency in the meat industry. However, Ambroziak (2016) assumed in his study that the Polish meat industry reached its strongest competitive position within all the Member States (MS) in 2008-2012. Mroczek (2015) stated that the Polish meat industry, and the poultry industry in particular, made good use of the opportunity for dynamic development and expansion into foreign markets which opened in 2004. Polish meat-processing plants are quite modern across the EU, but the comparative advantages of the Polish meat industry are slowly decreasing. Mroczek (2015) proposes an increase in capacity utilisation and labour productivity, to optimise production costs, and to foster innovation and modern sales channels. Small enterprises dominate among meat-processing plants in Poland, and about $60 \%$ of livestock holdings own herds smaller than 50 animals (Gozdowski, 2017). Vertical and horizontal integration in the meat sector would help to face seasonal price fluctuations for raw meat and other emerging risks (Milan, 2017).

Meat and meat product adulteration undermines the reputation of Polish meat industry, and influences its competitive position. Although luxury-food items

${ }^{2}$ Main Agricultural and Food Products Quality Inspection website http://www.ijhar-s.gov.pl. 
(olive oil, honey, herbs and spices) are perceived to be more likely to be targeted by fraudsters (Moore, Spink and Lipp, 2012; Silvis et al., 2017), there is potentially a greater risk of cumulative financial and personal harm from foods which are purchased more often, and in larger amounts. This forms the research rationale for why meat and meat products are the focus of this research.

\section{MATERIALS AND METHODS}

The aim of the paper was to recognize the scale and types of the food adulteration practices associated with meat and meat products from Poland. The discussion was mainly based on the analysis of data on the prevalence of food adulteration in meat and meat products (including poultry) drawn from the IJHARS site. The material comprised IJHARS administrative decisions regarding adulterated agri-food products, issued between 30.11.2015 and 30.04.2018, since IJHARS is obliged to make all the decisions public in November 2018. Decisions available as PDF documents were used to build a database in MS Excel. Such a decision contains the number and release date of the decision, the name of the adulterated product, the number of the production batch and the date of production, the batch volume, the confirmed irregularities, and the name of the business operator which produced or placed the adulterated food on the market.

The analyses were supplemented with information coming from the EU-reporting level. Since the
2017 annual report of the EU FFN \& SAAFF was too general, the author requested data from the EC, Directorate General Health and Food Safety in Brussels, Belgium, regarding alleged violations involving meat and poultry, and received them in May 2018.

\section{RESULTS AND DISCUSSION}

Publicly available IJHARS administrative decisions, comprising 244 adulterated meat and meat products (including poultry) marketed by 127 operators located in all voivodships of Poland, were analysed in this study. Half the items were reported in 2016, 40\% in 2017, and only $10 \%$ in 2015 and 2018. The large majority of the products were sausages $(n=160)$ (Fig. 1), including 'classic' medium minced sausages (106), snarlers (23), coarse minced sausages (18), weisswursts (7), meat sticks (5), and frankfurters (1). Ham (15) and tenderloin (6) dominated in the adulterated premium cold-meat products category $(n=30)$. Canned meat (6) was the major category in adulterated cold meat in the lower-price segment $(n=16)$. The main categories within adulterated fresh/frozen meat and offal $(n=21)$ were mincemeat (8) and chicken breast (5). Kebabs (12) were the most commonly adulterated ready-to-eat product. Not surprisingly pork-derived products were the most commonly adulterated items (Fig. 1) since the products were the most popular amongst Polish consumers (Stańko and Mikuła, 2016).

$95 \%$ of the IJHARS decisions regarding adulterated meat-derived products were issued under Article

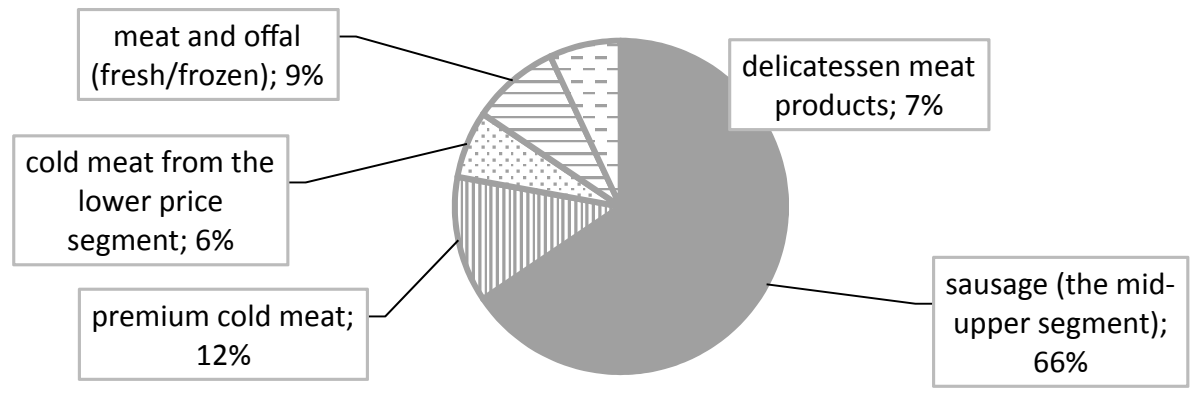

Figure 1. The categories of reported-on meat and meat products in Poland within IJHARS administrative decisions concerning adulterated agri-food items (30.11.2015-30.04.2018)

Source: own elaboration based on IJHARS data. 


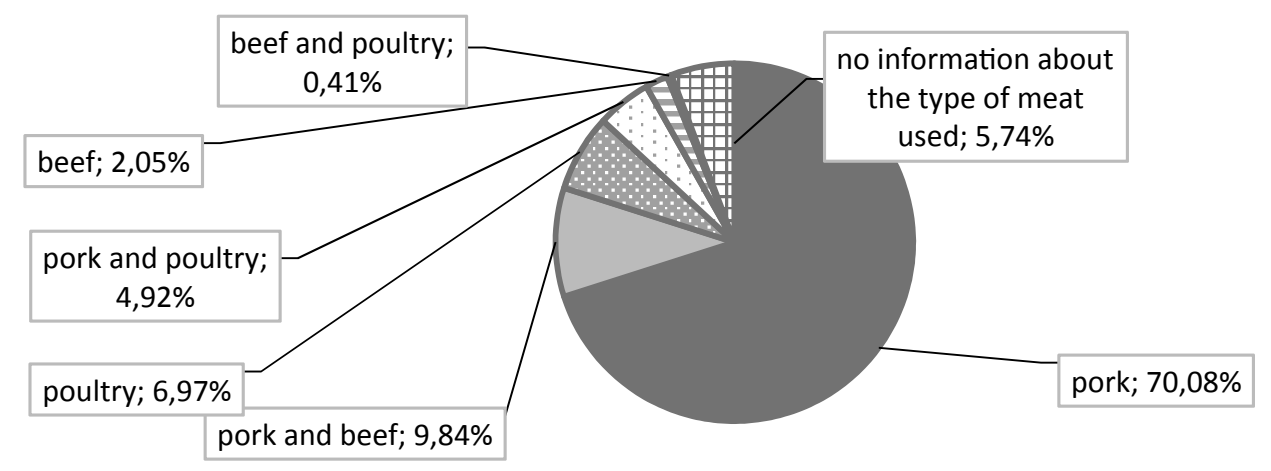

Figure 2. The structure of adulterated meat and meat products reported on by IJHARS per type of meat (30.11.2015-30.04 .2018 )

Source: own elaboration based on IJHARS data.

40a ACQAFP, in which financial penalties for food adulteration were established. The producers of the remaining 12 items were banned from placing food on the market, and/or were obliged to destroy or reprocess it, etc. (Article 29.1 of ACQFP). The idea was to make adulteration of food unprofitable and to contribute to the state budget.

The large majority of adulterated meat and meat products $(95 \%)$ were reported on due to violation of Article 7.1(a) of Regulation 1169/2011 concerning fair food-information practices and simultaneously Article 3.10 of ACQFP concerning (a) product changes designed to conceal its intrinsic composition or other properties, (b) misnomers, (c) incorrect and misleading information with regard to composition, country of origin or place of provenance, durability, net content or commercial quality class. The most common violations were:

- mislabelling: composition (197; $80.2 \%$ of all the cases) - missing items in the list of ingredients (135; 55.3\%); no/incomplete information on the composition of the compound ingredient (56; $23 \%$ ); the incorrect indication of the meat content $(39 ; 16 \%)$; the declaration of ingredients not used in the production process $(38 ; 15.6 \%)$; the incorrect indication of the added-water content (34; $13.9 \%)$; the presence of an undeclared type of meat $(33 ; 13.5 \%)$; no/incorrect information about the type of sausage casing $(22 ; 9 \%)$; the incorrect indication of the fat content $(17 ; 7 \%)$; a lack of information on potential allergens (17; 7\%); misleading information about the presence of mechanically separated meat (16;6.6\%);

- mislabelling: misnomers $(59 ; 24.2 \%)$ - incorrect/incomplete (descriptive) name of the product, e.g. the unfounded claim 'country sausage' (15; $6.1 \%)$;

- mislabelling: the falsification of shelf life (15; $6.1 \%)$.

The types of mislabelling have been differentiated by product. Composition is the major area of noncompliance in respect of cold meat and delicatessens. The most reported-on alleged violations for fresh meat were: (1) the product did not meet the requirements as to water content, and (2) the unauthorised extending of the life of the meat product.

The data received from the EC regarding foodfraud cases (AAC FF) and other non-compliance cases (AAC AA) exchanged in the EU FFN \& SAAFF in 2017 revealed that most violations for meat, poultry and their products were associated with mislabelling (Fig. 3). It can be expected that the kinds of alleged violations would vary among different types of meat used (Fig. 3). The most reported-on AAC FF 2017 for poultry-derived products were associated with: water content, unapproved establishment/cold stores, the falsification of shelf life, and illegal trade. The most reportedon AAC FF 2017 for meat-derived products (other than poultry) were: the substitution of beef by other species/the falsification of ingredients, the falsification of equine passports/documents, mislabelling 


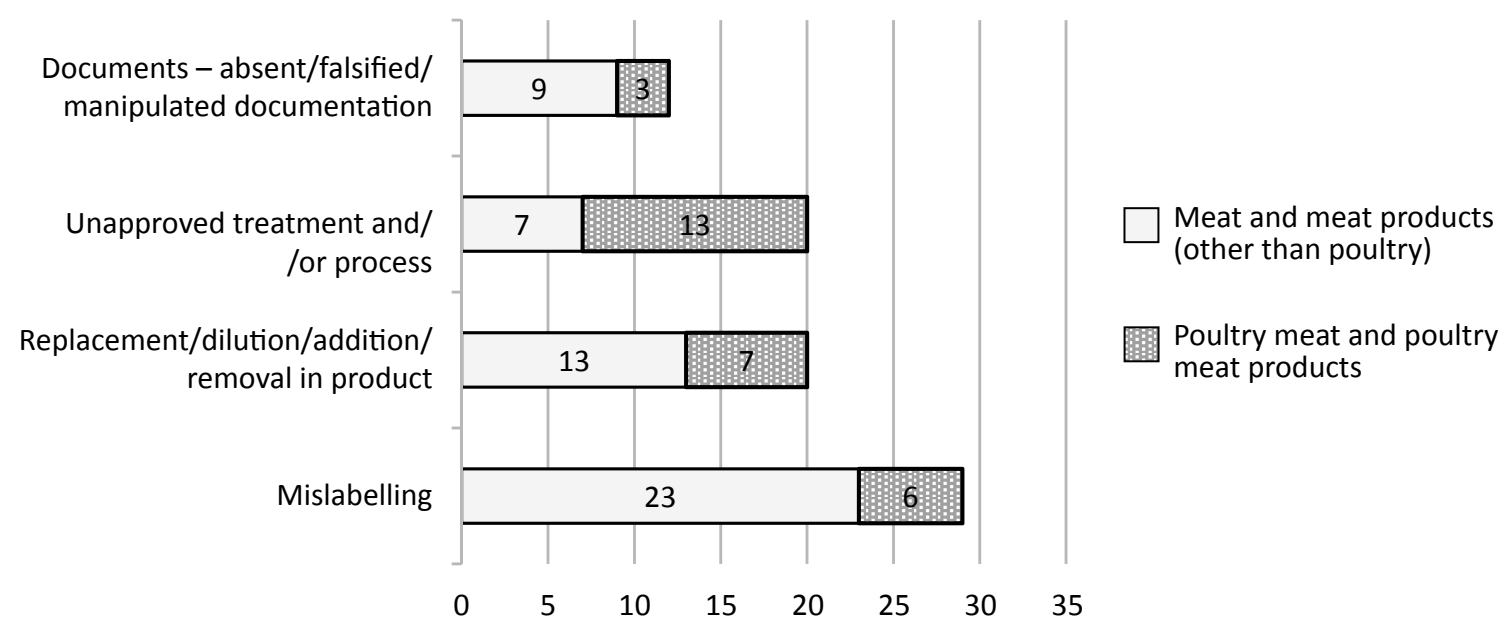

Figure 3. AAC FF and AAC AA for meat and poultry listed in 2017

Source: unpublished data received from the European Commision in May 2018.

(e.g. the indication of fat content incompatible with the meat denomination), the illegal export of pork meat (to third countries), unauthorised veterinary drugs, the unauthorised use of additives, unhygienic practices/expired consumption dates. The overall data of 2017 coming from the EU FFN \& SAAFF showed that $45 \%$ of all the violations were connected with mislabelling, 28\% - replacement/dilution/ addition/removal in product, $18 \%$ - unapproved treatment and/or process, and $9 \%$ - documents.

The limitation of this study is that the numbers coming from the EU FFN \& SAAFF are not exhaustive, as the use of the system by the MS to report non-compliances is not compulsory. There is a problem when attempting to compare non-compliances detected by IJHARS and reported to the EU FFN \& SAAFF. Above all, Polish food-control institutions deal with food adulteration and the EU system deals with food fraud and other non-compliances with a cross-border impact. However, a common tendency is to consider mislabelling as the most frequent problem.

\section{CONCLUSIONS}

As Poland is one of the top producers and exporters of meat and meat products in the EU, there is further potential for marketing and exporting a variety of
Polish meat-derived products. As the food chain becomes more global, it is crucial that IJHARS remain vigilant in ensuring the safety and legality of food products, especially with regard to product labelling. In Poland, mislabelling is the most common problem when it comes to meat and meat products adulteration, and it is in line with the non-compliances reported on by the MS to the EU FFN \& SAAFF. Mislabelling is in the unfair-information-practices spectrum, and impinges on the economic interests of consumers and meat-industry customers. Since all the administrative decisions regarding adulterated agri-food products have only been publicised on the IJHARS site since the end of 2015, it is hard to say whether the scale of meat and meat products adulteration has been growing in Poland. Nevertheless, globalisation is definitely expanding the scope and scale of food adulteration. As IJHARS decisions regarding adulterated food are publicised, it is probably just a question of time until the buyers of Polish meat and meat products will become aware of the problem, and the competitive advantage of the Polish meat industry will start to decline. Greater consumer knowledge about food-adulteration issues might undermine their trust in food. Rising awareness of the emerging risks should also lead to the increased use of management systems regarding food fraud/adulteration. 


\section{REFERENCES}

1. Act of 21 December 2000 on Commercial Quality of Agricultural and Food Products. Journal of Laws 2000 No 5, item 44, as amended.

2. Act of 25 August 2006 on the Safety of Food and Nutrition. Journal of Laws 2006 No 171, item 1225, as amended.

3. Ambroziak, Ł. (2016). Dekompozycja zmian eksportu rolno-spożywczego Polski z wykorzystaniem metody stałych udziałów w rynku [Decomposition of changes in agricultural and food export of Poland using the method of stable market shares]. In: Szczepaniak, I. (ed.) Konkurencyjność polskich producentów żywności i jej determinanty [Competitiveness of Polish food producers and its determinants]. IERiGŻ-PIB, Warszawa, pp. 77-92.

4. Chechelski, P., Kwasek, M., Mroczek, R. (2016). Zmiany $\mathrm{w}$ otoczeniu przemysłu spożywczego zachodzące pod wpływem globalizacji. Wybrane problemy [Changes in the surrounding of food industry caused by globalisation. Selected problems]. Studies and Monographs. IERiGŻ-PIB, Warszawa, pp. 178-182.

5. European Commission (2016). EU Food Fraud Network and the System for Administrative Assistance \& Food Fraud. Annual report. Retrieved from: https://ec.europa. $\mathrm{eu} /$ food/sites/food/files/safety/docs/food-fraud_network_activity_report_2016.pdf [Accessed 08.06.2017].

6. Eurostat (2015). Meat production statistics. Retrieved from: http://ec.europa.eu/eurostat/statistics-explained/ index.php/Meat_production_statistics [Accessed 07.04.2018].

7. Gozdowski, P. (2017). Przemysł mięsny się zmienia. Retrieved from: https://www.pb.pl/przemysl-miesnysie-zmienia-860477 [Accessed 09.05.2018].

8. GUS (2016). Agriculture 2015. Statistical Information and Elaborations. Dział Wydawnictw Statystycznych, Warszawa.

9. GUS (2017). Domestic deliveries and consumption of selected consumer goods per capita. 2016. Dzial Wydawnictw Statystycznych, Warszawa. Retrieved from: https://stat.gov.pl/en/topics/prices-trade/trade/ domestic-deliveries-and-consumption-of-selected-consumer-goods-per-capita-in-2016,9,6.html [Accessed 5.04.2018].

10. Janiuk, I., Jarosiński, M., Ribberink, N. (2015). Comparative study of Polish and Dutch meat industry exports with the example of top Polish meat exporters exploiting international opportunities. Przedsiębiorczość Międzynarodowa, 1 (2), pp. 9-26.
11. Korzycka, M., Wojciechowski, P. (2017). System prawa żywnościowego [Food law system]. Wolters Kluwer, Warszawa.

12. Kosicka-Gębska, M., Gębski, J., Kwiecińska, K., Jeznach, M., Tul-Krzyszczuk, A. (2017). Współczesne trendy w konsumpcji mięsa [Contemporary trends in meat consumption]. Przemysł Spożywczy, 71 (3), pp. 8-12.

13. Kowalczyk, S. (2015). Authenticity of food products in the Polish market checked during 2005-2012. Annals of the National Institute of Hygiene, 66 (1), pp. 27-34.

14. Kowalska, A. (2017). System wymiany informacji o oszustwach żywnościowych w Unii Europejskiej (The EU Information Exchange Systems for Food Fraud]. Przedsiębiorczość i Zarządzanie, 17 (9), Part 1, pp. 71-85.

15. Manning, L. (2016). Food Fraud, policy and food chain. Current Opinions in Food Science, 10, pp. 16-21. https://doi.org/10.1016/j.cofs.2016.07.001

16. Manning, L., Soon, J.M. (2014). Developing systems to control food adulteration. Food Policy, 49 (1), pp. 23 -32. https://doi.org/10.1016/j.foodpol.2014.06.005

17. Marvin, H.J.P., Bouzembrak, Y., Janssen, E.M., van der Fels-Klerx, H.J., van Asselt, E.D., Kleter, G.A. (2016). A holistic approach to food safety risks: Food fraud as an example. Food Research International, 89 (1), pp. 463-470. http://dx.doi.org/10.1016/j.foodres.2016.08.028

18. Milan, M. (2017). Rynek mięsny w natarciu [Meat market is attacking]. Gazeta Finansowa, 24-30.11.

19. Moore, J.C., Spink, J., Lipp, M. (2012). Development and application of a database of food ingredient fraud and economically motivated adulteration from 1980 to 2010. Journal of Food Science, 77 (4), pp. 118-126. http://dx.doi.org/10.1111/j.1750-3841.2012.02657.x

20. Moyer, D.C., DeVries, J.W., Spink, J. (2017) The economics of a food fraud incident - Case studies and examples including Melamine in Wheat Gluten. Food Control, 71, pp. 358-364. http://dx.doi.org/10.1016/ j.foodcont.2016.07.015

21. Mroczek, R. (2015). Determinanty i perspektywy rozwoju przemysłu mięsnego i drobiarskiego w Polsce w warunkach integracji z Unią Europejską [Determinants and development prospects for the meat and poultry industry during the Polish integration process with the European Union]. Zeszyty Naukowe SGGW w Warszawie. Problemy Rolnictwa Światowego, 15 (30), 1, pp. 58-67.

22. Pawlonka, T. (2017). Specyfika sektora przetwórstwa mięsnego w Unii Europejskiej - stan i perspektywy [The specifity of meat processing sector in the European Union - condition and perspectives]. Zagadnienia Ekonomiki Rolnej, 1 (350), p. 180. 
23. Regulation (EC) No 178/2002 of the European Parliament and of the Council of 28 January 2002 laying down the general principles and requirements of food law, establishing the European Food Safety Authority and laying down procedures in matters of food safety. OJ L 31 of 01.02.2002.

24. Regulation (EU) $2017 / 625$ of the European Parliament and of the Council of 15 March 2017 on official controls and other official activities performed to ensure the application of food and feed law, rules on animal health and welfare, plant health and plant protection products. OJ L 95 of 07.04.2017.

25. Regulation (EU) No 1169/2011 of the European Parliament and of the Council of 25 October 2011 on the provision of food information to consumers. OJ L 304 of 22.11.2011.

26. Silvis, I.C.J., van Ruth, S.M., van der Fels-Klerx, H.J., Luning, P.A. (2017). Assessment of food fraud vulnerability in the spices chain: An explorative study. Food Control, 81, pp. 80-87. http://dx.doi.org/10.1016/ j.foodcont.2017.05.019

27. Spink, J., Moyer, D.C. (2011). Defining the Public
Health Threat of Food Fraud. Journal of Food Science 76(9), pp. 157-163. http://dx.doi.org/10.1111/j.17503841.2011.02417.x

28. Spink, J., Ortega, D.L., Chen, Ch., WU, F. (2017). Food fraud prevention shifts the food risk focus to vulnerability. Trends in Food Science \& Technology, 62, pp. 215-220. http://dx.doi.org/10.1016/j.tifs.2017.02.012

29. Stańko, S., Mikuła, A. (2016). Tendencje w produkcji, zużyciu krajowym i handlu zagranicznym wieprzowiną, wołowiną i mięsem drobiowym w Polsce w latach 2000-2015 [Trends in production, domestic consumption and foreign trade of pork, beef and poultry meat in Poland in the years 2000-2015]. Roczniki Naukowe Ekonomii Rolnictwa i Rozwoju Obszarów Wiejskich, 103 (2), pp. 31-40.

30. Supreme Administrative Court (2013). The Judgment of 6 February 2013 on the liability for placing adulterated butter on the market. II GSK 2171/11.

31. Voivodship Administrative Court (2010). The Judgement of 15 December 2010 on the legal basis of liability for placing adulterated agricultural and food product on the market. VI SA/Wa 1553/10. 